\title{
Exchange between macrophyte and mangrove organic matter input in estuarine systems: drought implications
}

\begin{abstract}
Paq proxy was applied on mid and long-chain $n$-alkanes in order to develop an index to assist in the long-term assessment of changes and exchanges between aquatic communities in estuarine environments as a result of increased saline incursion. New boundaries are proposed according to $n$-alkanes abundance in the leaves of local mangrove tree species for better definition of emergent aquatic plant end-member. Molecular distribution and d $13 \mathrm{C}$ isotopic signatures of $\mathrm{n}$-alkanes were also used to support the parameter. A predominance of odd carbon-numbered

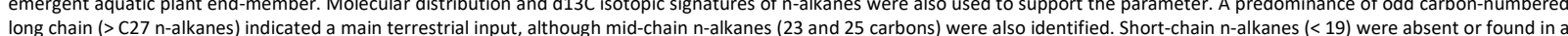
very small concentration. Carbon Preference Index and C/N ratio reinforced a terrestrial origin for the sedimentary organic matter. d13C signatures of $n$-alkanes for C23, C25, C29 and C 31 very small concentration. Carbon Preference Index and C/N ratio reinforced a terrestrial origin for the sedimentary organic matter. d13C signatures of $n$-alkanes for C23, C25, C29 and C31
were characteristic of mangrove input, ranging from - $27.57 \%$ (C23) to -34.40\% (C29) for Piraquê-Mirim River (PM) and from - $27.36 \%$ (C23) to -32.84 \%o (C31) for Piraquê-Açu River (PA) without any particular trend. Paq proxy was successfully used to identify rises in marine macrophytes (mid-chain $n$-alkanes) input mainly in the confluence and PM probably as consequence of drought periods. The confluence presented a mixing sources of OM. PA was identified as a stable mangrove environment while PM was characterized by pulses of marine macrophytes input and should be managed with care in respect to its catchment for water use and dam constructions as a shortage of fresh water can alter the estuarine ecology.
\end{abstract}

Keywords: Carbon Isotopes; Alkanes; Mangrove; Macrophyte; Drought.

\section{Alteração entre aporte de matéria orgânica oriunda de macrófitas e de mangues em sistemas estuarinos: implicações de seca}

\begin{abstract}
O índice Paq foi aplicado em n-alcanos de cadeia média e longa afim de desenvolver um índice para auxiliar na avaliação de longo prazo de mudanças e trocas entre comunidades aquáticas em ambientes estuarinos como resultado do aumento de intrusão salina. Novos limites são propostos de acordo com a abundância de n-alcanos nas folhas de espécies de mangues locais para uma melhor definição dos limites considerados para plantas aquáticas emergentes. A distribuição molecular e as assinaturas isotópicas d13C de n-alcanos também foram utilizadas para corroborar com este novo parâmetro. Uma predominância de cadeia carbônica longa e ímpar (> C27) indicou um aporte terrestre dominante, embora n-alcanos de cadeia média (23 e 25 carbonos) também foram identificados. Os n-alcanos de cadeia curta (<19) estiveram ausentes ou foram encontrados em uma concentração muito baixa. O Índice de Preferência de Carbono e a relação $\mathrm{C} / \mathrm{N}$ reforçaram uma origem terrestre para a matéria orgânica sedimentar. As assinaturas d13C de $\mathrm{n}$-alcanos para $\mathrm{C} 23, \mathrm{C} 25, \mathrm{C} 29$ e $\mathrm{C} 31$ foram características de matéria orgânica e a relação $\mathrm{C} / \mathrm{N}$ reforçaram uma origem terrestre para a matéria orgânica sedimentar. As assinaturas d13C de $\mathrm{n}$-alcanos para $\mathrm{C} 23, \mathrm{C} 25$, C29 e C31 foram características de matéria orgânica
oriunda de mangues, variando de $-27,57 \%$ (C23) a $-34,40 \%$ (C29) para o rio Piraquê-Mirim (PM) e de $-27,36 \%$ (C23) a - $32,84 \%$ \% (C31) para o rio Piraquê-Açu (PA), sem qualquer tendência específica. $O$ índice Paq foi utilizado com sucesso para identificar um aumento do aporte de matéria orgânica de macrófitas marinhas (n-alcanos de cadeia média), principalmente na confluência e no PM, provavelmente como consequência de períodos de seca. A confluência apresentou Sources de mistas de matéria orgânica. O PA foi identificado como um ambiente de manguezal estável, enquanto o PM foi caracterizado por pulsos de aporte de macrófitas marinhas e deve ser gerenciado com cuidado em relação à sua captação para uso de água e construções de barragens, uma vez que a escassez de água doce pode alterar a ecologia estuarina.
\end{abstract}

Palavras-chave: Isótopos de Carbono, Alcanos, Manguezais, Macrófitas, Seca.

Topic: Desenvolvimento, Sustentabilidade e Meio Ambiente

Reviewed anonymously in the process of blind peer.
Received: $10 / 04 / 2018$ Approved: 24/05/2018
Caroline Fiório Grilo (iD)

Universidade Federal do Espírito Santo, Brasil

$\frac{\text { http://lattes.cnpq.br/6229815133388209 }}{\text { http://orcid.org/0000-0003-4533-367X }}$

carolinegrilo@gmail.com

Eduardo Schettini Costa

Universidade Federal do Espírito Santo, Brasil

http://lattes.cnpq.br/0634794650368993

http://orcid.org/0000-0003-4813-7367

eduoceano@gmail.com

Renato Rodrigues Neto (it

Universidade Federal do Espírito Santo, Brasil

http://lattes.cnpq.br/1931267781220159

http://orcid.org/0000-0003-0803-4435

rrneto@gmail.com

d

DOI: 10.6008/CBPC2179-6858.2018.004.0007

\author{
George Wolff (D) \\ University of Liverpool, Reino Unido \\ http://orcid.org/0000-0002-9380-1039 \\ wolff@liverpool.ac.uk \\ Anu Thompson (iD) \\ University of Liverpool, Reino Unido \\ http://orcid.org/0000-0003-1444-9960 \\ anu@liverpool.ac.uk
}

\section{Referencing this:}

GRILO, C. F.; COSTA, E. S.; RODRIGUES NETO, R.; WOLFF, G.; THOMPSON, A.. Exchange between macrophyte and mangrove organic matter input in estuarine systems: drought implications. Revista Ibero Americana de Ciências Ambientais, v.9, n.4, p.83-98, 2018. DOI: http://doi.org/10.6008/CBPC2179-6858.2018.004.0007 


\section{INTRODUCTION}

Zonation of mangroves species is site specific as it is controlled by tidal inundation, soil pore water salinity, sediment stability and type and fresh water input (JIMÉNEZ et al., 1985; CARDONA et al., 1998; JIMÉNEZ, 1990; ELLISON, 1993; DUKE et al., 1998; ELSTER, 2000). Salinity is the most obvious influencing factor. Even congeneric species usually occupy distinct positions of intertidal zones due to differential ability of salt tolerance (LIANG et al., 2008). Despite mangroves have been adapted to salinity variations and even found in places with same salinity as the open sea (WOODROFFE, 1982), pore water salinization due to high evaporation rates and low freshwater inflow can result in hypersaline zones where mangroves cannot survive.

Surface water runoff from adjacent uplands and groundwater flow are important factors on hypersaline soil formation due to inhibition of salts accumulation in the pore water (BERTNESS et al., 1992; THIBODEAU, et al., 1998), but halophytic shrubs, herbs and grasses can develop in mangroves when fresh water inflow is too low (ELLISON et al., 1991; RAKOTOMAVO et al., 2010). Less rainfall can decrease mangrove diversity and extent, as mangrove requirements for tolerance of high salinity in soil reduce growth rate and mangrove productivity (FIELD, 1995; GILMAN et al., 2008).

Apart from changes in precipitation pattern, construction of dams upstream in the river may reduce fluvial inputs, nutrients and sediment (DUVIAL et al., 2007; SNOUSSI et al., 2007), resulting in biodiversity losses, alteration in structural aspects and swap of biological communities. A reduction in the fluvial flow may favours marine incursions into the estuary and may change environmental conditions for submerged aquatic vegetation settlement that lives below or at the water surface within estuaries and freshwater environments. It includes seagrasses, freshwater grasses and macroalgae species (KEMP et al., 2004; DENNISON et al.; 2008). Seagrasses are aquatic flowering plants that form meadows in near-shore brackish or marine waters in temperate and tropical regions and are able to live and complete their life cycle under submerged and haline conditions (DEN HARTOG et al., 2006).

Seagrass meadows and mangroves have been exposed to different anthropogenic impacts of varying intensity, and they may be vulnerable to different stresses according to climate and coastal dynamics and ecosystems resiliencies (COPERTINO et al., 2016). As drought has becoming an often problem in different places of the world, particularly in southeast Brazil, understand how major organic matter producers stand against fluvial flow shrinkage and rise in marine water intrusion is a matter of coastal management, as such ecosystem supports many others adjacent and provides many services (RÖNNBÄCK, 1999; VO et al., 2012; LEE et al., 2014). As mangrove sediment can provide historic records of past environmental conditions such as sea level change and climate variations, differences in hydrological conditions and productivity can be evaluated. Such differences may result in different organic matter inputs and reflect in the quality and degree of diagenesis of the sedimentary organic matter (JAFFÉ et al., 2001).

In order to develop an index to assist in the long-term assessment of changes and exchanges between aquatic communities in estuarine environments as a result of increased saline incursion, a multi-proxy 
approach based on $n$-alkanes chain length and their isotopic $\delta^{13} \mathrm{C}$ signature was applied in a typical drowned river valley with Y-shaped morphology, with a main channel towards the mouth (Piraquê-Açu-Mirim Estuarine System - PAMES; Brazil; Figure 1). Both estuarine branches are meandering systems with extensive mangroves and tidal flats (SILVA et al., 2013) with about $15.592 \mathrm{~km}^{2}$ around Açu River and about $14.790 \mathrm{~km}^{2}$ around Mirim River. The rivers have very different flow regimes due to their different drainage basins and catchment areas (13.69 and $2.59 \mathrm{~m}^{3} / \mathrm{s} ; 378.6$ and $469.4 \mathrm{~km}^{2}$ for PA and PM, respectively; BARROSO et al., 2012; LEITE, 2012), so they have different interactions with the incoming marine flow. The climate of the PAMES region is tropical with seasonal variations of temperature and humidity and an average annual rainfall of ca. $1250 \mathrm{~mm}$ (IEMA, 2010). The region presents two well-defined seasonal periods: a rainy season (October to March) with maximum precipitation between November and December (200-250 mm) (LEITE, 2012), average temperatures of ca. $32.4^{\circ} \mathrm{C}$ (FEITOZA, 1997) and predominance of north-easterly winds (CAMPOS, 2011); a dry period (May to August) with the lowest rainfall June and August (25-50 mm) (ALBINO et al., 2006), and with average temperature of ca. $14.9^{\circ} \mathrm{C}$ (FEITOZA, 1997). Although the PAMES has no anthropogenic limitation to block mangrove migration, the natural barrier of the Barreiras Formation (MARTIN et al., 1996) could restrict mangrove migration in case of sea level rise.

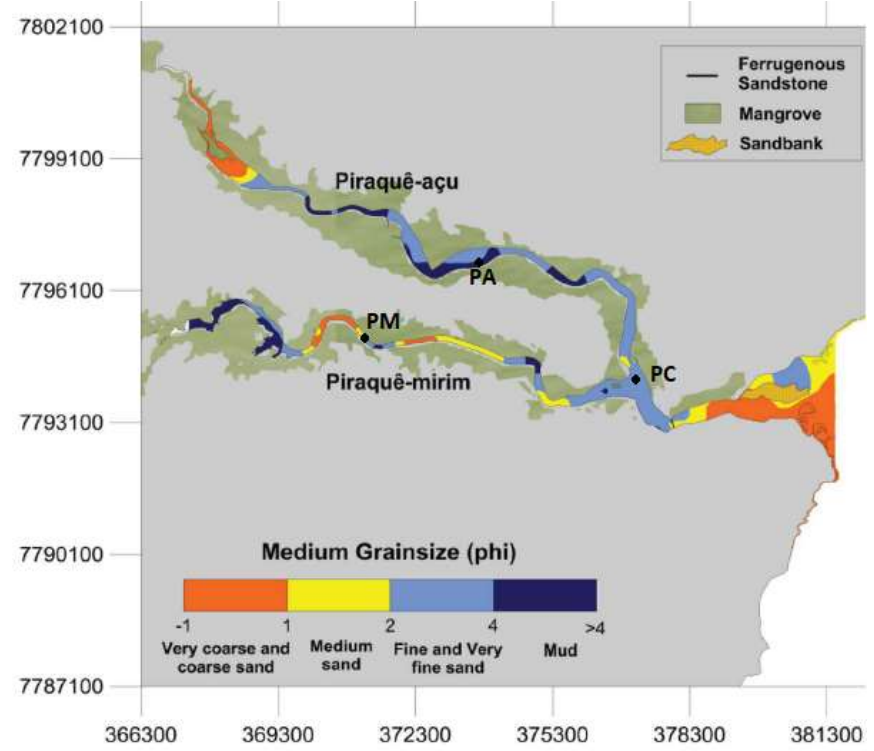

Figure 1: Map of Piraquê-Açu and Piraquê-Mirim Estuarine System (PAMES; Modified after Silva et al., 2014). Coring sites are indicated as black dots on the map.

\section{MATERIALS AND METHODS}

\section{Sampling}

Three sediment cores were collected in February 2010 with a push corer in the main channel at three different sites (Figure 1): Piraquê-Açu River upstream (PA, $74 \mathrm{~cm}$ length), Piraquê-Mirim River upstream (PM, $50 \mathrm{~cm}$ length) and at the confluence (PC, $96 \mathrm{~cm}$ length). Sampling sites were selected using seismic data of the channel bottom where the sediment layers showed little disturbance. All cores were frozen $\left(-20{ }^{\circ} \mathrm{C}\right)$ and then sliced at $2 \mathrm{~cm}$ intervals. The first 10 centimetres were sliced at $1 \mathrm{~cm}$ interval. Samples were then freezedried (under vacuum at $-60^{\circ} \mathrm{C}$ ) and stored $\left(-20^{\circ} \mathrm{C}\right.$ ) until analysis. 


\section{Elemental composition ( $\mathrm{C} / \mathrm{N}$ molar ratio)}

Freeze-dried and macerated sediments (ca. $100 \mathrm{mg}$ ) were decarbonated by acid treatment $(\mathrm{HCl} 10$ $\%)$ and the carbonate content was determined by gravimetry. Elemental analyses were carried out using a Costech ECS 4010 analyser for quantification of organic carbon and total nitrogen present in the sediment and mean values were taken (S.D $<10 \%$ of the mean).

\section{n-Alkanes analysis}

Freeze-dried sediments (ca. $1 \mathrm{~g}$ ) were macerated and sonicated with dichloromethane (DCM): methanol $(9: 1 \mathrm{v} / \mathrm{v})(3 \times 15 \mathrm{~min})$. Extracts were combined and concentrated in vacuuo (to ca. $1 \mathrm{~mL}$ ) and transferred to a small vial. Sulphur was removed with pre-activated copper $(\mathrm{HCl} 37 \%$, followed by doubledistilled water, methanol and DCM wash). The residue was dissolved in DCM and any residual water was removed by drying the extract over anhydrous sodium sulphate. $n$-Alkanes (apolar fraction) were recovered with $4 \mathrm{~mL}$ of hexane using a small silica gel column (70-230 microns; Pasteur pipette), with lipid extracts dispersed on alumina. All solvents were distilled or HPLC grade. Sodium sulphate and silica gel were extracted with DCM $(24 \mathrm{~h})$ and heated $\left(400^{\circ} \mathrm{C} ; 12 \mathrm{~h}\right)$.

Quantification and identification were performed on a Trace Gas Chromatograph 2000 Series (ThermoQuest) coupled to a Mass Spectrometer ThermoQuest Finnigan Triple-Stage Quadrupole 7000 with electron impact ionization. A silica capillary column $(60 \mathrm{~m}, 0.25 \mathrm{~mm}, 10 \mu \mathrm{m}$ Agilent J \& W DB-5MS) was used with helium as carrier gas at a constant flow. The injections were made manually on the on-column mode and the column flow rate was $1.2 \mathrm{~mL} / \mathrm{min}$. The oven heating program began at an initial temperature of 60 ${ }^{\circ} \mathrm{C}$ for $1 \mathrm{~min}$, followed by a ramp from $170{ }^{\circ} \mathrm{C}$ at $6{ }^{\circ} \mathrm{C} / \mathrm{min}$ and after, $315^{\circ} \mathrm{C}$ at $2.5^{\circ} \mathrm{C} / \mathrm{min}$ hold by $12 \mathrm{~min}$. The MS electron impact was operated in the full scan mode in a range from 50 to 600 Thompsons per second and ionization energy of $70 \mathrm{eV}$. The ion source temperature was $215{ }^{\circ} \mathrm{C}$ and the interface, $320{ }^{\circ} \mathrm{C}$. Data was processed using Xcalibur software. Compounds were identified either by comparison of their mass spectra and relative retention indices with those available in the literature and/or by comparison with authentic standards. Quantitative data were calculated by comparison of peak area of the internal standard $5 \alpha(\mathrm{H})-$ cholestane using the total ion current chromatogram. A lipid standard containing a mixture of compounds (fatty acids, coprostanol, epicoprostanol, cholesterol, cholestanol, stigmastanol, stigmasterol, 37:2 ketone, $\mathrm{C}_{20}$ and $\mathrm{C}_{24}$ alcohols, and $5 \alpha(\mathrm{H})$-cholanic acid) was injected before each batch of samples to determine response factors for quantification. Samples were corrected with individual blanks when needed, although in most cases lipid levels were insignificant ( $<1 \%$ of the sample values). Concentrations were normalized to total organic carbon (TOC) content of the sediments.

\section{n-Alkanes specific isotope analysis}

Compound Specific Isotope Analysis (CSIA) was carried out on a Delta V Advantage (Thermo Fisher, Bremen) coupled with an Ultra Trace auto sampler TriPlus with ConFio IV interface and $1 \mu \mathrm{L}$ splitless mode 
injection into a silica capillary column (J\&W Scientific DB5, $30 \mathrm{~m}, 0.25 \mathrm{mmdi}, 0.25 \mu$ film thickness). The oven heating program had an initial temperature of $45^{\circ} \mathrm{C}$ for $1 \mathrm{~min}$ followed by a ramp up to $295^{\circ} \mathrm{C}$ at $6{ }^{\circ} \mathrm{C} / \mathrm{min}$ for 15 minutes. The injector was held at $280^{\circ} \mathrm{C}$. Ultra-pure helium was used as carrier gas at a constant flow rate of $1.4 \mathrm{ml} / \mathrm{min}$. The Gas Chromatograph was operated in the back flush mode during the initial period of solvent elution while helium was passed in the opposite direction through the reactor combustion. Isotopic compositions represent the mean of duplicate or triplicate analyses and standard deviations were $\leq 0.5 \%$. The $\mathrm{CO}_{2}$ reference gas was calibrated externally relative to the standard Vienna Pee Dee Belemnite (VPDB) in a double mass spectrometer inlet. The results are presented in per mil (\%o) to VPDB standard. Data were acquired and processed using ISODAT software. External standards containing fatty acids (Arndt Schimmelmann, Indiana University) $\delta^{13} \mathrm{C}$ values precisely known were analysed at each batch sample.

\section{RESULTS AND DISCUSSION}

\section{n-Alkanes distribution}

C/N ratios for PM (23.52 to 53.95; Figure 2) and for PA (23.28 to 32.25; Figure 3) cores were greater than 20 and indicate a major input of terrestrial organic matter, while PC (15.44 to 34.45; Figure 4) profile presented intermediate values (15.44 to 18.86) mainly on the top (first $6 \mathrm{~cm}$ ), suggesting a phytoplankton organic matter deposition rise in more recent sediments (values between 4 and 10 are an indicative of phytoplankton origin and values $>20$ of terrestrial input) (MEYERS et al., 1993; MEYERS, 1997). A smooth rising trend of phytoplankton input was also identified in the PM core from base to the top, as $\mathrm{C} / \mathrm{N}$ ratio presented a progressive reduction.

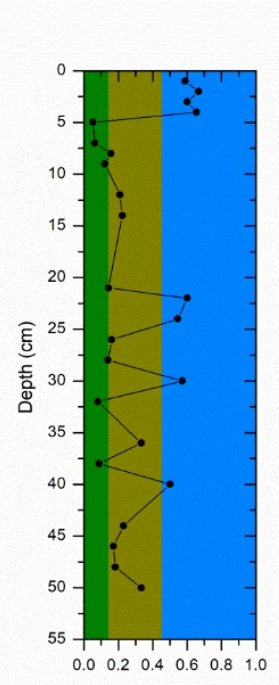

$\mathrm{Paq}$

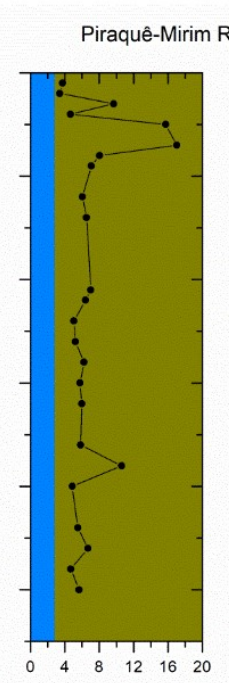

CPI

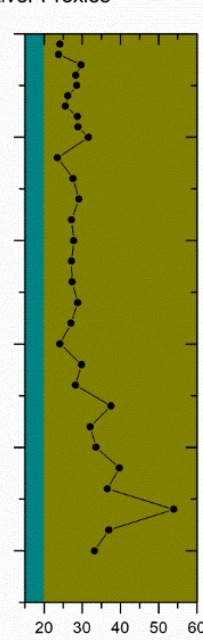

$\mathrm{C} / \mathrm{N}$

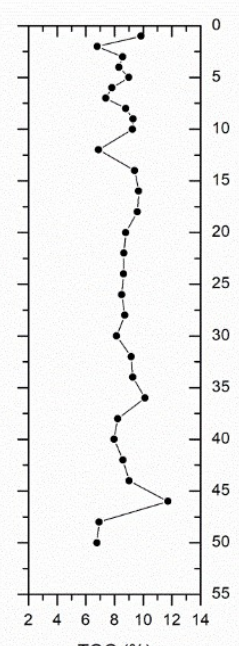

TOC (\%)

Figure 2: Piraquê-Mirim Proxies are described as $\mathrm{Paq}=\left(\mathrm{C}_{23}+\mathrm{C}_{25}\right) /\left(\mathrm{C}_{23}+\mathrm{C}_{25}+\mathrm{C}_{29}+\mathrm{C}_{31}\right)$; Carbon Preference Index $=$ $0,5^{*}\left(\right.$ Lodd $C_{25}$ to $C_{33} /$ Leven $C_{24}$ to $\left.C_{32}\right) /\left(\right.$ Lodd $C_{25}$ to $C_{33} /$ Leven $C_{26}$ to $\left.C_{34}\right), C / N$ ratio and Total Organic Carbon (\%). Green colour represents terrestrial input, brown represents mangrove input, blue represents marine input and cyan represent mixed environment. 


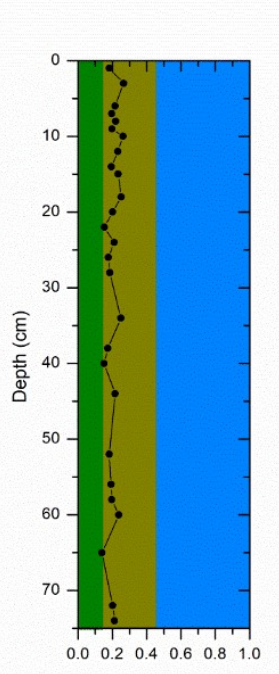

$\mathrm{Paq}$

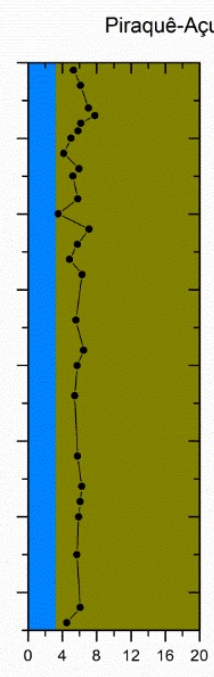

$\mathrm{CPI}$

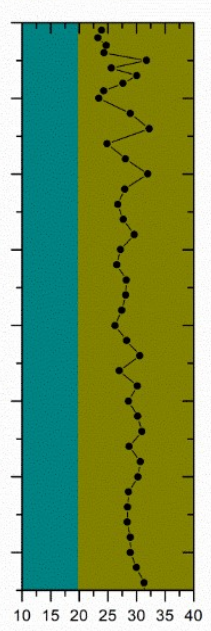

$\mathrm{C} / \mathrm{N}$

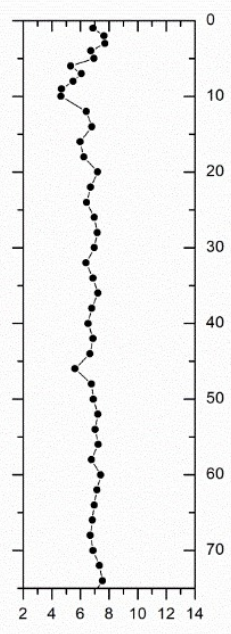

TOC $(\%)$

Figure 3: Piraquê-Açu Proxies are described as Paq $=\left(C_{23}+C_{25}\right) /\left(C_{23}+C_{25}+C_{29}+C_{31}\right)$; Carbon Preference Index $=0,5^{*}(\Sigma o d d$ $\mathrm{C}_{25}$ to $\mathrm{C}_{33} /$ Leven $\mathrm{C}_{24}$ to $\left.\mathrm{C}_{32}\right) /\left(\right.$ Lodd $\mathrm{C}_{25}$ to $\mathrm{C}_{33} /$ Leven $\mathrm{C}_{26}$ to $\left.\mathrm{C}_{34}\right), \mathrm{C} / \mathrm{N}$ ratio and Total Organic Carbon (\%). Green colour represents terrestrial input, brown represents mangrove input, blue represents marine input and cyan represent mixed environment.

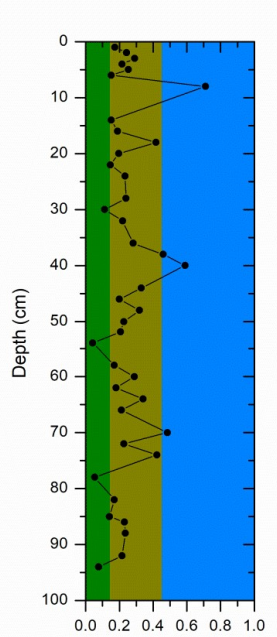

Paq

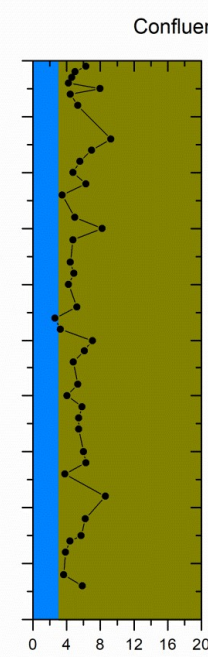

$\mathrm{CPI}$

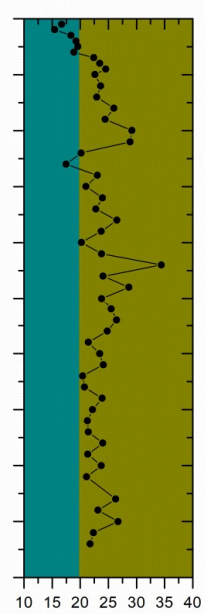

$\mathrm{C} / \mathrm{N}$

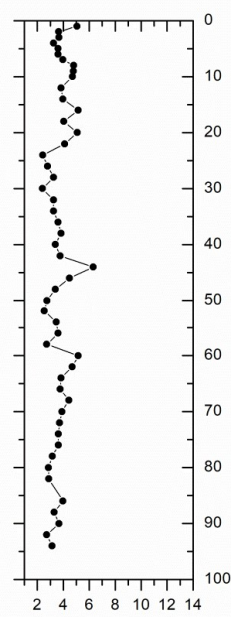

TOC $(\%)$

Figure 4: Confluence Proxies are described as Paq $=\left(C_{23}+C_{25}\right) /\left(C_{23}+C_{25}+C_{29}+C_{31}\right)$; Carbon Preference Index $=0,5^{*}(\Sigma o d d$ $\mathrm{C}_{25}$ to $\mathrm{C}_{33} /$ Leven $\mathrm{C}_{24}$ to $\left.\mathrm{C}_{32}\right) /\left(\right.$ Lodd $\mathrm{C}_{25}$ to $\mathrm{C}_{33} /$ Leven $\mathrm{C}_{26}$ to $\left.\mathrm{C}_{34}\right), \mathrm{C} / \mathrm{N}$ ratio and Total Organic Carbon (\%). Green colour represents terrestrial input, brown represents mangrove input, blue represents marine input and cyan represent mixed environment.

The most abundant $n$-alkanes in the three cores were those of long-chain length (> 25 carbons) with a strong dominance of odd over even and a unimodal distribution with a maximum at $\mathrm{C}_{29}$ homologue (Figures 5, 6 and 7), implying a major input of higher plants (EGLINTON et al., 1967) due to its great abundance in cuticular waxes (CRANWELL, 1973; REDDY et al., 2000; WANG et al., 2003). The great abundance of $\mathrm{C}_{27}$ and $\mathrm{C}_{31}$ homologues is also an indicative of higher plant waxes input (EGLINTON et al., 1967; CRANWELL, 1973). As the surrounded vegetation is composed by mangroves, another higher plant source is unlikely and allows long-chain $n$-alkanes to be used as mangrove markers to the estuary, reflecting on higher values of CPI (> 3), indicating an input prevalence of $n$-alkanes from higher plants waxes (BRAY et al., 1961; CHIKARAISHI et al., 2003; EGLINTON et al., 1967; VAN DONGEN et al., 2008) for the three cores (4.69 to 10.59 for PM; 1.92 to 7.8 for PA; 2.63 to 9.26 for PC; Supplementary Data 1; Figure 2, 3 and 4). 

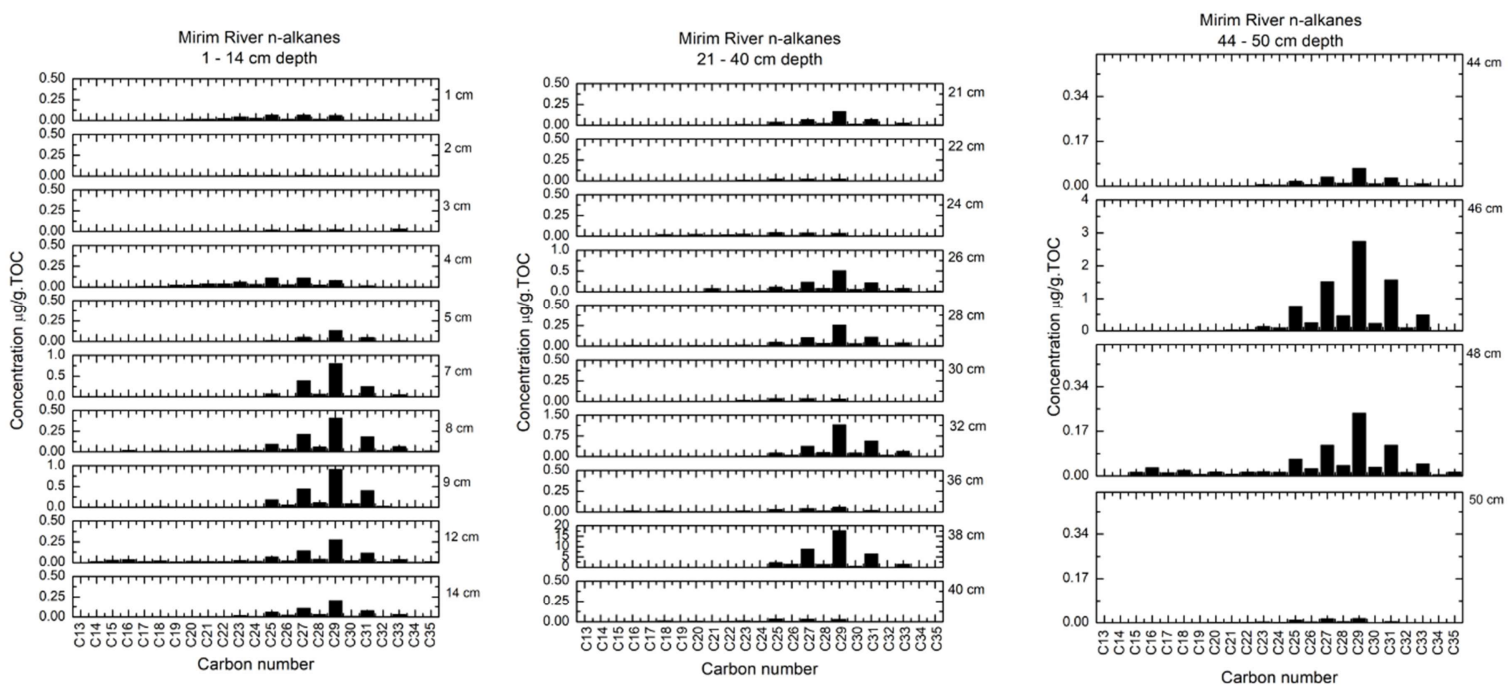

Figure 5: n-Alkanes abundance ( $\mu \mathrm{g} / \mathrm{g}$.TOC) for Piraquê-Mirim River. Y-axes are not standardized while X-axes range is from 13 to 35 carbons.
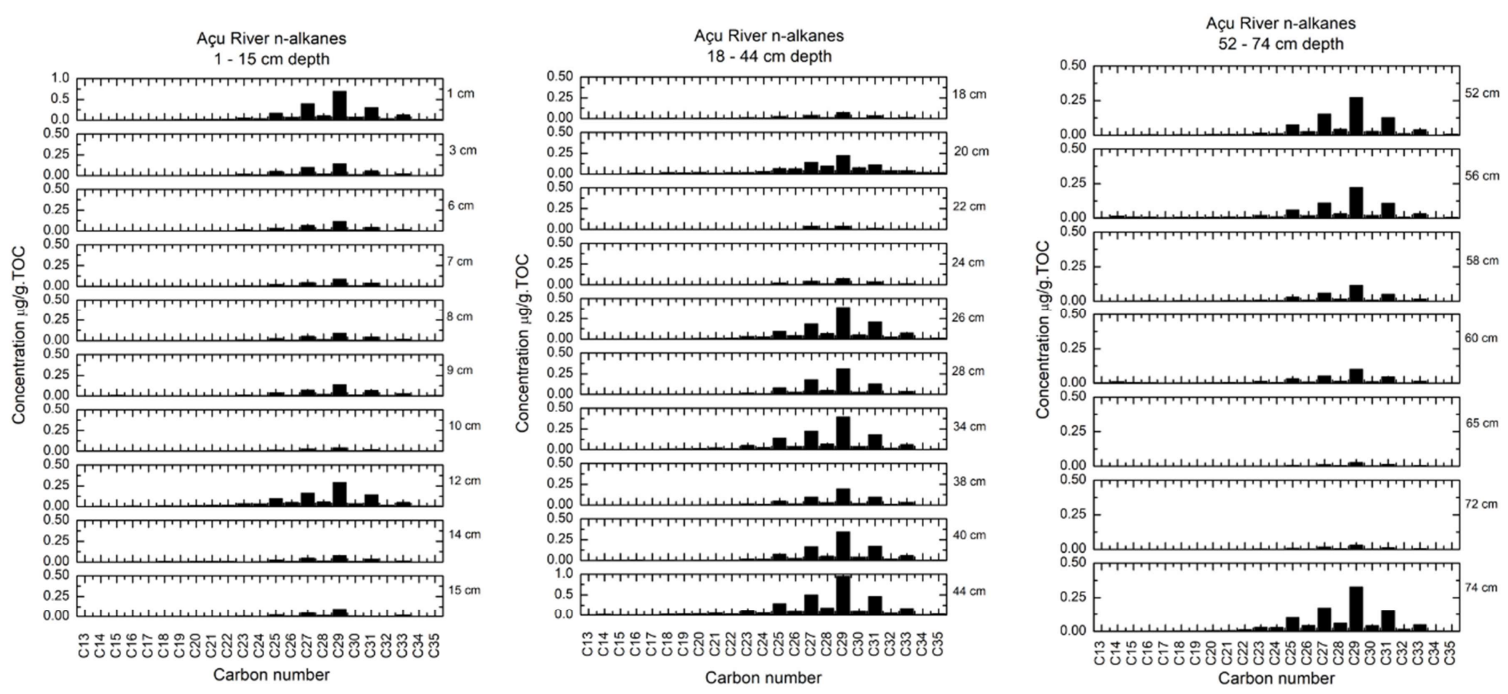

Figure 6: $\mathrm{n}$-Alkanes abundance ( $\mu \mathrm{g} / \mathrm{g} . \mathrm{TOC})$ for Piraquê-Açu River. Y-axes are not standardized while $\mathrm{X}$-axes range is from 13 to 35 carbons.
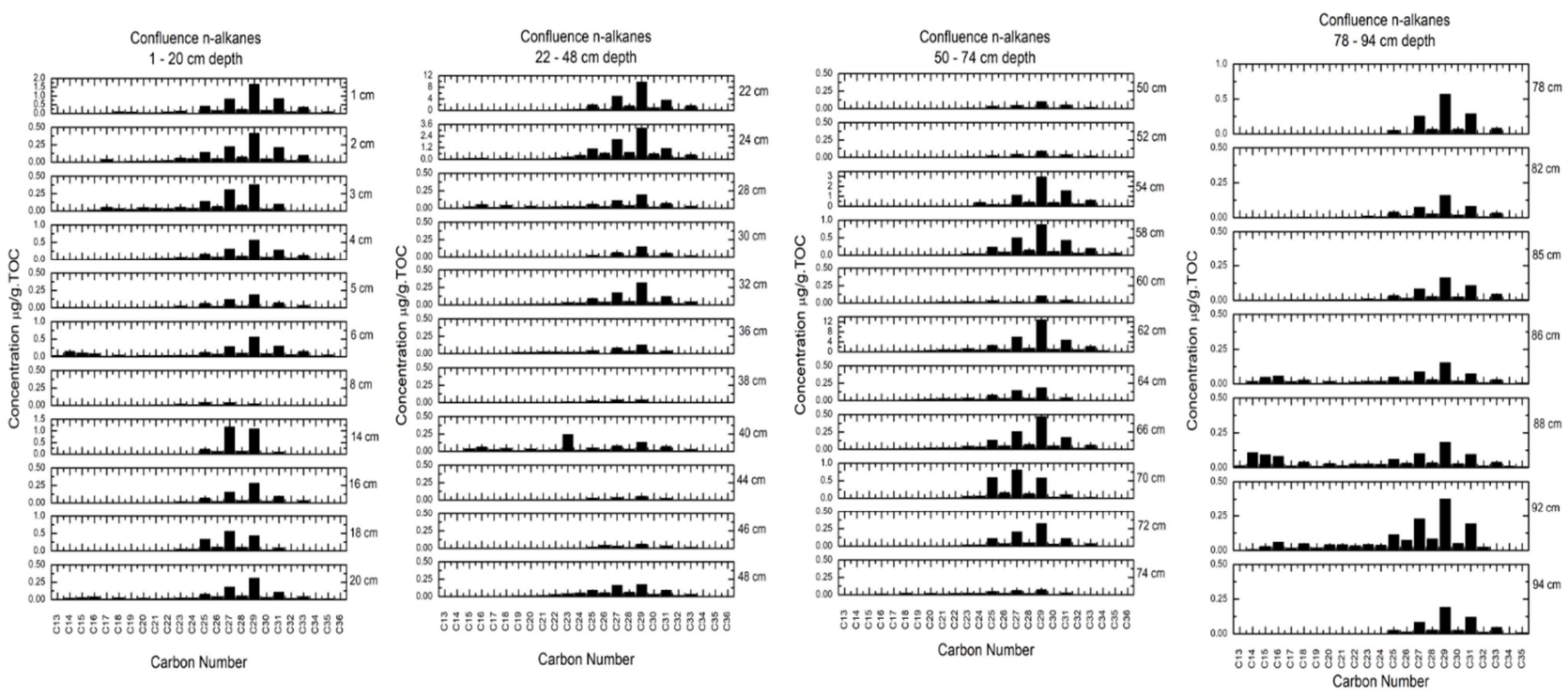

Figure 7: n-Alkanes abundance ( $\mu$ g/g.TOC) for Confluence. Y-axes are not standardized while X-axes range is from 13 to 35 carbons. 
Supplementary data 1: Data acquired for Piraquê-Mirim (PM), Piraquê-Açu (PA) and Confluence (PC). Blank cells are the core limit. $\mathrm{C} / \mathrm{N}$ ratio $>20$ are indicative of terrestrial origin, while $<10$ are indicative of aquatic sources. $\mathrm{CPI}<3$ are indicative of aquatic origin, while $>3$, terrestrial. Paq $<0.15$ are indicative of terrestrial inputs; $0.15-0.45$ of emergent aquatic plants; $>0.45$ are aquatic plants and marine macrophytes.

\begin{tabular}{|c|c|c|c|c|c|c|c|c|c|}
\hline \multirow[b]{2}{*}{ Depth (cm) } & \multicolumn{3}{|l|}{ PM } & \multicolumn{3}{|l|}{ PA } & \multicolumn{3}{|l|}{ PC } \\
\hline & CPI & $\mathrm{C} / \mathrm{N}$ & Paq & CPI & $\mathrm{C} / \mathrm{N}$ & Paq & CPI & $\mathrm{C} / \mathrm{N}$ & Paq \\
\hline 1 & 3.72 & 24.16 & 0.59 & 5.3 & 23.93 & 0.18 & 6.28 & 16.67 & 0.17 \\
\hline 2 & 3.4 & 23.85 & 0.67 & $\mathrm{nc}$ & 23.28 & 0.26 & 5.0 & 15.44 & 0.24 \\
\hline 3 & 9.67 & 29.69 & 0.6 & 6.12 & 24.7 & $\mathrm{nc}$ & 4.61 & 18.35 & 0.28 \\
\hline 4 & 4.65 & 28.34 & 0.65 & $\mathrm{nc}$ & 24.35 & $\mathrm{nc}$ & 4.22 & 19.27 & 0.22 \\
\hline 5 & 15.72 & 28.58 & 0.05 & $\mathrm{nc}$ & 31.78 & $\mathrm{nc}$ & 7.96 & 19.57 & 0.24 \\
\hline 6 & 17.02 & 26.27 & $\mathrm{nc}$ & 7.06 & 25.64 & $\mathrm{nc}$ & 4.43 & 18.86 & 0.16 \\
\hline 7 & 8.05 & 25.63 & 0.06 & 7.8 & 30.07 & 0.19 & $\mathrm{nc}$ & 22.41 & $\mathrm{nc}$ \\
\hline 8 & 7.07 & 28.71 & 0.16 & 6.14 & 27.66 & 0.24 & 5.33 & 23.47 & 0.75 \\
\hline 9 & $\mathrm{nc}$ & 28.86 & 0.12 & 5.85 & 24.29 & 0.2 & $\mathrm{nc}$ & 24.52 & $\mathrm{nc}$ \\
\hline 10 & 6.05 & 31.57 & $\mathrm{nc}$ & 5 & 23.44 & 0.33 & $\mathrm{nc}$ & 22.62 & $\mathrm{nc}$ \\
\hline 12 & 6.51 & 23.52 & 0.21 & 4.15 & 28.91 & 0.23 & $\mathrm{nc}$ & 23.64 & $\mathrm{nc}$ \\
\hline 14 & $\mathrm{nc}$ & 27.63 & 0.22 & 5.94 & 32.25 & 0.21 & 9.26 & 22.95 & 0.15 \\
\hline 16 & 7.02 & 29.15 & $\mathrm{nc}$ & 5.21 & nc & 0.25 & 6.98 & 26.01 & $\mathrm{nc}$ \\
\hline 18 & 6.4 & 27.24 & $\mathrm{nc}$ & 5.81 & 24.89 & $\mathrm{nc}$ & 5.59 & 24.42 & 0.2 \\
\hline 20 & 5.06 & 27.73 & $\mathrm{nc}$ & 3.5 & 28.09 & 0.23 & 4.76 & 29.19 & 0.42 \\
\hline 22 & 5.23 & 27.22 & $\mathrm{nc}$ & 7.1 & 31.96 & 0.21 & 6.3 & 28.89 & 0.19 \\
\hline 24 & 6.24 & 27.36 & 0.14 & 5.76 & 27.94 & $\mathrm{nc}$ & 3.49 & 20.19 & $\mathrm{nc}$ \\
\hline 26 & 5.77 & 28.83 & 0.6 & 4.85 & 26.71 & 0.17 & $\mathrm{nc}$ & 17.47 & 0.15 \\
\hline 28 & 5.96 & 27.06 & 0.55 & 6.3 & 27.68 & 0.2 & 4.99 & 23.04 & 0.23 \\
\hline 30 & $\mathrm{nc}$ & 24.13 & 0.16 & $\mathrm{nc}$ & 29.6 & 0.18 & 8.21 & 21.03 & $\mathrm{nc}$ \\
\hline 32 & 5.84 & 29.82 & 0.14 & $\mathrm{nc}$ & 27.21 & 0.19 & 4.76 & 23.97 & 0.26 \\
\hline 34 & 10.59 & 28.24 & 0.57 & 5.58 & 26.57 & $\mathrm{nc}$ & $\mathrm{nc}$ & 22.76 & 0.09 \\
\hline 36 & 4.86 & 37.51 & 0.08 & $\mathrm{nc}$ & 28.24 & $\mathrm{nc}$ & 4.46 & 26.5 & 0.21 \\
\hline 38 & $\mathrm{nc}$ & 32.06 & $\mathrm{nc}$ & 6.49 & 28.12 & 0.25 & 4.86 & 23.74 & $\mathrm{nc}$ \\
\hline 40 & 5.5 & 33.58 & 0.33 & 5.74 & 27.41 & $\mathrm{nc}$ & 4.23 & 20.21 & 0.27 \\
\hline 42 & 6.69 & $\mathrm{nc}$ & 0.09 & $\mathrm{nc}$ & 26.23 & 0.17 & $\mathrm{nc}$ & 23.81 & 0.44 \\
\hline 44 & 4.69 & 39.7 & 0.5 & 5.45 & 28.26 & 0.16 & 5.22 & 34.45 & 0.59 \\
\hline 46 & 5.66 & 36.54 & $\mathrm{nc}$ & $\mathrm{nc}$ & 30.59 & $\mathrm{nc}$ & 2.63 & 24.08 & $\mathrm{nc}$ \\
\hline 48 & 3.72 & 53.95 & $\mathrm{nc}$ & $\mathrm{nc}$ & 26.98 & $\mathrm{nc}$ & 3.27 & 28.68 & $\mathrm{nc}$ \\
\hline 50 & 3.4 & 36.98 & 0.23 & $\mathrm{nc}$ & 30.13 & 0.22 & 7.07 & 23.78 & 0.36 \\
\hline 52 & & & & 5.76 & 28.63 & $\mathrm{nc}$ & 6.1 & 25.52 & 0.25 \\
\hline 54 & & & & $\mathrm{nc}$ & 30.2 & $\mathrm{nc}$ & 4.81 & 26.45 & 0.33 \\
\hline 56 & & & & 6.27 & 30.97 & $\mathrm{nc}$ & $\mathrm{nc}$ & 24.79 & 0.21 \\
\hline 58 & & & & 6.08 & 28.73 & 0.18 & 5.32 & 21.44 & 0.19 \\
\hline 60 & & & & 5.89 & 30.67 & $\mathrm{nc}$ & 4.06 & 23.47 & 0.04 \\
\hline 62 & & & & $\mathrm{nc}$ & 30.27 & 0.2 & 5.84 & 24.11 & $\mathrm{nc}$ \\
\hline 64 & & & & $\mathrm{nc}$ & 28.61 & 0.19 & 5.43 & 20.42 & 0.17 \\
\hline 66 & & & & 5.71 & 28.45 & 0.21 & 5.45 & 20.74 & 0.3 \\
\hline 68 & & & & $\mathrm{nc}$ & 28.4 & $\mathrm{nc}$ & $\mathrm{nc}$ & 23.89 & 0.18 \\
\hline 70 & & & & $\mathrm{nc}$ & 28.91 & $\mathrm{nc}$ & 6 & 22.22 & 0.35 \\
\hline 72 & & & & $\mathrm{nc}$ & 28.94 & 0.2 & 6.28 & 21.27 & $\mathrm{nc}$ \\
\hline 74 & & & & 6.07 & 30.02 & 0.21 & 3.8 & 21.44 & 0.41 \\
\hline 76 & & & & $\mathrm{nc}$ & 31.34 & $\mathrm{nc}$ & $\mathrm{nc}$ & 24.03 & $\mathrm{nc}$ \\
\hline 78 & & & & & & & 8.61 & 21.36 & 0.05 \\
\hline 80 & & & & & & & $\mathrm{nc}$ & 23.72 & $\mathrm{nc}$ \\
\hline 82 & & & & & & & 6.21 & 21.14 & 0.17 \\
\hline 85 & & & & & & & 5.73 & $\mathrm{nc}$ & 0.13 \\
\hline 86 & & & & & & & 4.41 & 26.33 & 0.24 \\
\hline 88 & & & & & & & 3.87 & 23.15 & 0.25 \\
\hline 90 & & & & & & & $\mathrm{nc}$ & 26.76 & $\mathrm{nc}$ \\
\hline 92 & & & & & & & 3.67 & 22.35 & 0.21 \\
\hline 94 & & & & & & & 5.88 & 21.77 & 0.09 \\
\hline
\end{tabular}

$\mathrm{nc}=$ not calculated

$\mathrm{CPI}=0,5^{*}($ Lodds $\mathrm{C} 25$ to $\mathrm{C} 33 /$ Leven C24 a C32)/(Lodd C25 to C33/Leven C26 to C34)

$\mathrm{Paq}=[\mathrm{C} 23+\mathrm{C} 25] /[\mathrm{C} 23+\mathrm{C} 25+\mathrm{C} 29+\mathrm{C} 31]$

Source: Ficken et al. (2000). 
Carbon chains between $\mathrm{C}_{15}$ and $\mathrm{C}_{25}$ without odd or even predominance are considered an indicative of reworked autochthonous organic matter (GRIMALT et al., 1990), mainly $C_{15}$ and $C_{17}$ homologues (CRANWELL, 1982), or petrogenic input (JAFFÉ et al., 2001). n-Alkanes between $\mathrm{C}_{14}$ and $\mathrm{C}_{19}$ can also be considered as an indicative of phytoplankton input (SIKES et al., 2009), mainly $\mathrm{C}_{17}$ homologue (ORO et al., 1967; BLUMER et al., 1971). Short chain $n$-alkanes $\left(<C_{21}\right)$ were identified in very low abundance compare to their long-chains counterparts, mostly with $\mathrm{C}_{16}$ and $\mathrm{C}_{18}$ homologues as more abundant and only in some depths at PM $(1,4,8,12,24$, and $48 \mathrm{~cm}$; Figure 5), PA (12, 20, 34, 44, 56 and $74 \mathrm{~cm}$; Figure 6) and PC (1-4, 6, $20,24,28,36,40,64,74,86-92 \mathrm{~cm}$; Figure 7).

Because conventional $n$-alkane source apportionment techniques, such as CPI, do not account for mid-chain length sources that can be prevalent in coastal environments, they may suggest low terrestrial inputs (SIKES et al., 2009) or do not account for submerged macrophytes producers. A lesser input of mid chains $n$-alkanes $\left(21,23\right.$ and 25 carbons) was also identified with $C_{25}$ predominance over $C_{23}$ in the three cores (except for PC at $40 \mathrm{~cm}$ ). The presence of $n$-alkanes between $C_{21}$ and $C_{25}$ with odd over even predominance is an indicative of a potential input of aquatic macrophytes and/or macroalgae (FICKEN et al., 2000; JEFFÉ et al., 2001; MEAD et al., 2005). Submerged and floating plants present higher abundances of $\mathrm{C}_{21}, \mathrm{C}_{23}$ and/or $\mathrm{C}_{25}$ homologues (CRANWELL, 1984; OGURA et al., 1990; VISO et al., 1993) while emergent macrophytes present a similar distribution to higher plants, having as most abundant homologues those with more than 27 carbons (JOHNSON et al., 1955; CRANWELL, 1984). A potential input of $n$-alkanes from aquatic macrophytes (submerged and/or floating) can be better evaluated by a proxy ratio comparing the relative contribution of those derived from macrophytes $\left(C_{23}\right.$ to $\left.C_{25}\right)$ versus emergent and higher plants $\left(C_{29}\right.$ to $C_{31}$; FICKEN et al., 2000).

The proxy Paq is described as [C23+C25]/[C23+C25+C29+C31], where low values $(<0.1)$ correspond to terrestrial plants, mid values $(0.1-0.4)$ to emergent macrophytes and high values (> 0.4) to submerged/floating macrophytes (FICKEN et al., 2000). Values near the boundaries can be an indicative of a mixed input. Although emergent macrophyte considered in the Paq index was applied for a lacustrine environment, mangrove species also present as majoritarian $n$-alkane the $C_{29}$ homologue (Table 1). Paq values has been reported between 0.88 and 0.99 for marine macrophytes, 0.24 for Rizophora. mangle, between 0.44 and 0.53 for a mix between terrestrial and seagrass input and an increasing trend towards the open sea (MEAD et al., 2005, XU et al., 2006; ANKITA et al., 2017). Some improvement in the Paq boundaries was made by the inclusion of marine macrophytes and mangroves as end-members (SIKES et al., 2009) for its application in coastal environments (Pmar-aq proxy) but did not fit well in the present study.

It seems that the difficult of applying the Paq and Pmar-aq proxies lies on the values for mangrove boundaries. The abundance of $n$-alkanes among the three Brazilian species of mangrove (Rhizophora mangle, Avicennia schaueriana and Laguncularia racemosa) are different and is also variable between leaves maturity (Table 1). While the natural process of decaying promotes an accumulation of $n$-alkanes in senescent leaves, plants under water stress due to salinization and/or drought may produce more $n$-alkanes in their leaves for protection against evapotranspiration (BELLIGOTTI et al., 2007) and shift the Paq values boundaries for 
mangroves input. By making an average of Paq for the three mangrove species and for both senescent and green leaves, proxy value for major mangrove input becomes 0.2. Considering the natural standard deviation ( \pm 0.27 in the present work), the proposed boundaries became $<1.5$ to terrestrial plants, mid values (1.54.5 ) to emergent aquatic plants (including mangroves) and high values (> 4.5) to aquatic plants and marine macrophytes (Figures 2, 3 and 4).

Table 1: $n$-Alkanes abundance $\left(\mu \mathrm{g} \cdot \mathrm{g}^{-1} \cdot \mathrm{TOC}^{-1}\right)$ for mangrove leaves. RZ = Rizophora mangle, LA = Laguncularia racemosa, $\mathrm{AV}=$ Avicennia schaueriana. $\mathrm{G}=$ green leaf, $\mathrm{S}=$ senescent leaf.

\begin{tabular}{|c|c|c|c|c|c|}
\hline Carbon number & RZ G & RZ S & LA G & LAS & AV G \\
\hline $\mathrm{C} 13$ & nd & nd & nd & 0.20 & nd \\
\hline $\mathrm{C} 14$ & nd & 0.10 & nd & 0.34 & nd \\
\hline $\mathrm{C} 15$ & nd & 0.05 & nd & nd & nd \\
\hline C16 & nd & 0.12 & nd & 0.18 & nd \\
\hline $\mathrm{C} 17$ & nd & nd & nd & 0.08 & nd \\
\hline $\mathrm{C} 18$ & nd & 0.06 & nd & 0.16 & nd \\
\hline C19 & nd & 0.04 & nd & 0.13 & nd \\
\hline $\mathrm{C} 20$ & 0.03 & 0.06 & nd & 0.27 & nd \\
\hline $\mathrm{C} 21$ & 0.05 & 0.06 & nd & 0.24 & nd \\
\hline $\mathrm{C} 22$ & 0.10 & 0.10 & nd & 0.26 & nd \\
\hline $\mathrm{C} 23$ & 0.1 & 0.17 & nd & nd & nd \\
\hline $\mathrm{C} 24$ & 0.10 & 0.11 & nd & 0.35 & nd \\
\hline $\mathrm{C} 25$ & 0.16 & 0.5 & 0.46 & 2.37 & 0.28 \\
\hline $\mathrm{C} 26$ & 0.04 & 0.08 & 0.37 & 1.29 & 0.49 \\
\hline $\mathrm{C} 27$ & 0.15 & 0.87 & 10.78 & 28.26 & 8.04 \\
\hline $\mathrm{C} 28$ & 0.06 & 0.10 & 0.92 & 4.91 & 0.49 \\
\hline $\mathrm{C} 29$ & 0.11 & 1.09 & 22.83 & 83.06 & 4.78 \\
\hline $\mathrm{C} 30$ & nd & 0.07 & nd & 1.37 & 0.10 \\
\hline C31 & nd & 0.54 & nd & 2.11 & 0.9 \\
\hline $\mathrm{C} 32$ & nd & nd & nd & nd & nd \\
\hline C33 & nd & nd & nd & nd & nd \\
\hline C34 & nd & nd & nd & nd & nd \\
\hline C35 & nd & nd & nd & nd & nd \\
\hline $\mathrm{Paq}$ & 0.70 & 0.29 & 0.02 & 0.03 & 0.05 \\
\hline
\end{tabular}

${ }^{*}$ nd $=$ not detected;

${ }^{*} \mathrm{Paq}=(\mathrm{C} 23+\mathrm{C} 25) /(\mathrm{C} 23+\mathrm{C} 25+\mathrm{C} 29+\mathrm{C} 31)$

Source: Ficken et al. (2000).

As expected, PA profile is very stable and is kept from the base to the top inside the mangrove boundaries. PM and PC profiles swapped between all three zones, but a greater influence of terrestrial input appears in PM. The core retrieved from the confluence presented the greatest variation of proxies due to rivers meet with the sea, having a high sedimentary dynamic with deposition followed by bottom erosion (SILVA et al., 2014). Despite Piraquê-Açu and Piraquê-Mirim rivers meet in the same estuary they present different catchment area resulting in a distinct fluvial flow and interaction with the income of marine incursions, where Piraquê-Açu holds a greater fluvial flow. A minor river outflow imposes a weak barrier against marine waters incursions, mostly during periods of dry weather, characterized by greater macrophyte inputs (Paq > 0.45) in PM and PC cores. The greater intrusion of marine waters during dry periods can be confirmed by the increase of mean salinity of the water column from $29.38 \pm 2.1$ to $34.32 \pm 1.1$ as the rainfall decrease in the PAMES, having a minima (25.66 \pm 1.5 in March and $25.82 \pm 1.9$ in December) in the PiraquêAçu River and a maxima (36.96 \pm 0.6 in September) in the confluence during the winter, when the intrusion of marine waters is stronger (MONTEIRO et al., 2017). 


\section{Isotope Analysis}

It is important to note that chain length-based parameters cannot distinguish uniquely between submerged macrophytes versus marine sources nor can they distinguish well between riverine delivery of emergent aquatic material versus local coastal mangrove inputs without additional parameters to a better discrimination of the organic detritus (SIKES et al., 2009). In an attempt to enhance our capacity to discriminate among organic matter sources, compound specific carbon stable isotope ratio measurement were performed in the sediment cores on the $n$-alkanes $\left(C_{23}, C_{25}, C_{29}, C_{31}\right)$ used to determine the Paq proxy.

Carbon isotope ratios in plants are regulated by photosynthetic fixation of $\mathrm{CO}_{2}$, making signature of most terrestrial plants typically falls within two groups, $C_{3}$ or $C_{4}$. Terrestrial and emergent vegetation present similar carbon isotopic composition, while the marine and submerged freshwater vegetation are quite different (MEAD et al., 2005) due to differences in the photosynthetic pathway (O'LEARY, 1981). Although seagrasses are $\mathrm{C}_{3}$ plants, they use bicarbonate instead of $\mathrm{CO}_{2}$ as a carbon source, resulting in a $\mathrm{C}_{4}$-like $\delta^{13} \mathrm{C}$ enriched isotopic signature (BENEDICT et al., 1980; O'LEARY, 1981; HERNANDEZ et al., 2001).

$\mathrm{C}_{4}$ plants are enriched in $\delta^{13} \mathrm{C}$, ranging from -18 to $-25 \%$, while $\mathrm{C}_{3}$ plants have a comparatively larger isotopic discrimination, and their values range between -31 to -39 \% (DEINES, 1980; COLLISTER et al., 1994; SIMONEIT, 1997). Although organic matter source derived from mangroves ( $C_{3}$ plants $)$ is considered as a terrestrial input, $n$-alkanes $\delta^{13} \mathrm{C}$ values range between -35 and $-21 \%$ (BOUILLON et al., 2008). In contrast, marsh grasses, sea grasses, and marine macrophyte alkanes are more enriched (-13 to-22 \%o; CANUEL et al.,1997; FICKEN et al., 2000; MEAD et al., 2005) and can mask the terrestrial signal in coastal environments by contributing to the enriched isotopic signature of the $C_{23-25} n$-alkanes and $C_{25-27} n$-alkanes (SIKES et al., 2009), according to each species.

Values of $n$-alkanes $\delta^{13} \mathrm{C}$ signatures for $C_{23}, C_{25}, C_{29}$ and $C_{31}$ were inside the proposed limit for mangroves, ranging from $-27.57 \%$ o $\left(C_{23}\right)$ to $-34.40 \%$ o $\left(C_{29}\right)$ for $P M$ and from $-27.36 \%$ o $\left(C_{23}\right)$ to $-32.84 \%$ o $\left(C_{31}\right)$ for PA (Figure 8; Supplementary Data 2) and also presented values similar to previous signals reported for typically mangrove estuarine sites (-27.3\%o to $-31.9 \%$ for $C_{23}$ to $C_{29}$; MEAD et al., 2005), except for $C_{29}$ homologue (minimum of $-34.40 \%$ ) in the Piraquê-Mirim River. Isotopic signatures of each homologue were enriched by decreasing the carbon chain length, except for $\mathrm{C}_{29}$ in the PM core, where $\mathrm{C}_{29}$ was always heavier than $C_{31}$. As the major homologue in mangrove leaves is $C_{29}$, its isotopic enrichment is less significant than for $C_{23}$ and $C_{25}$, which is probably mainly derived from marine submerged vegetation. $\delta^{13} C$ values of $n$-alkanes from sediments cores did not show any particular trend, although $C_{29}$ and $C_{31}$ in the PM core presented standard deviation near $1 \%$ probably due to enhanced organic matter production from halophyte marsh grasses (like Spartina; Wang et al., 2003). Seagrasses are typically enriched relative to other estuarine producers, with most values between -16 and -12\%o (HEMMINGA and MATEO, 1996), but show remarkable variability in signature over short distances, with more depleted values close to the mangroves, varying almost $10 \%$ in less than 4 km distance (MARGUILLIER et al., 1997; FRANCE et al., 1997; MEAD et al., 2005). 

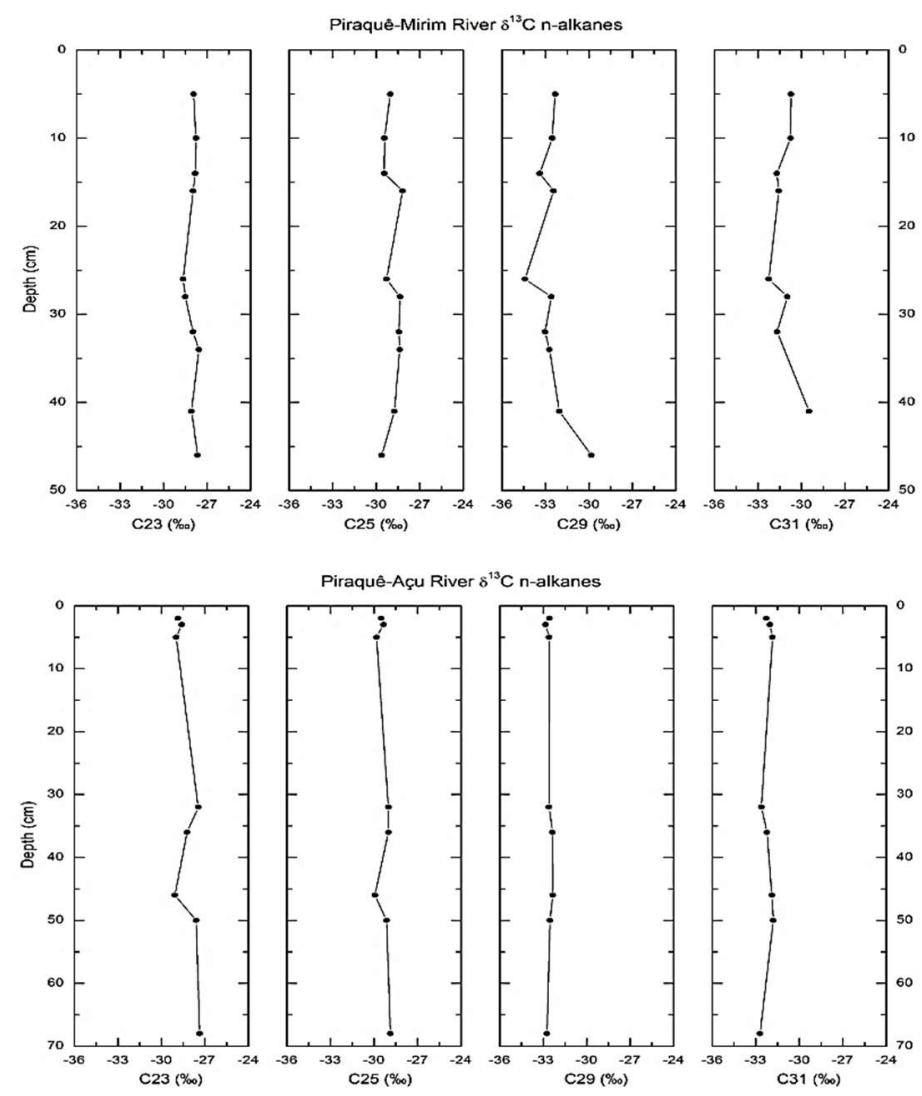

Figure 8: $\delta^{13} C(\%)$ Signatures of $n$-alkanes $\left(C_{23}, C_{25}, C_{29}\right.$ and $\left.C_{31}\right)$ used on Paq index for Piraquê-Mirim and Piraquê-Açu Rivers. $\mathrm{Y}$-axes are standardized for each river while $\mathrm{X}$-axes are standardized for both rivers.

Supplementary data 2: $\delta^{13} \mathrm{C}(\%)$ signatures of n-alkanes for Piraquê-Mirim (PM), Piraquê-Açu (PA) and Confluence (PC) cores. Minimum and maximum values for each homologue are shown at the end of the table.

\begin{tabular}{|c|c|c|c|c|c|c|c|c|}
\hline \multirow[b]{2}{*}{ Depth $(\mathrm{cm})$} & \multicolumn{4}{|c|}{ PM n-alkanes isotopes } & \multicolumn{4}{|c|}{ PA n-alkanes isotopes } \\
\hline & $\delta^{13} C_{23}(\%)$ & $\delta^{13} C_{25}(\% \circ)$ & $\delta^{13} C_{29}(\%)$ & $\delta^{13} C_{31}(\%)$ & $\delta^{13} C_{23}(\%)$ & $\delta^{13} C_{25}(\%$ ) & $\delta^{13} C_{29}(\%)$ & $\delta^{13} \mathrm{C} 31$ (\%o) \\
\hline 2 & na & na & na & na & -28.86 & -29.5 & -32.48 & -32.56 \\
\hline 3 & na & na & na & na & -28.59 & -29.35 & -32.2 & -32.84 \\
\hline 4 & na & na & na & na & na & -29.35 & -32.84 & na \\
\hline 5 & -27.93 & -29.03 & -32.32 & -30.73 & -28.98 & -29.82 & -32.66 & -32.58 \\
\hline 10 & -27.76 & -29.43 & -32.53 & -30.76 & na & na & na & na \\
\hline 14 & -27.82 & -29.44 & -33.39 & -31.7 & na & na & na & na \\
\hline 16 & -27.96 & -28.18 & -32.43 & -31.56 & na & na & na & na \\
\hline 26 & -28.65 & -29.29 & -34.4 & -32.26 & na & na & na & na \\
\hline 28 & -28.5 & -28.36 & -32.59 & -30.97 & na & na & na & na \\
\hline 32 & -27.97 & -28.43 & -33.03 & -31.69 & -28.98 & -29.82 & -32.66 & -32.58 \\
\hline 34 & -27.57 & -28.38 & -32.71 & na & na & na & na & na \\
\hline 36 & na & na & na & na & -28.23 & -29 & -31.52 & -32.35 \\
\hline 41 & -28.08 & -28.75 & -32.04 & -29.47 & na & na & na & na \\
\hline 42 & na & -28.75 & -32.04 & na & na & na & na & na \\
\hline 46 & -28.08 & -28.75 & -32.04 & -29.47 & -29.06 & -29.94 & -31.48 & -32.33 \\
\hline 48 & na & -29.62 & -29.83 & na & na & na & na & na \\
\hline 50 & na & na & na & na & -27.61 & -29.14 & -31.27 & -32.52 \\
\hline 68 & na & na & na & na & -27.36 & -28.86 & -31.02 & -32.74 \\
\hline Minimum & -27.57 & -28.18 & -29.83 & -29.47 & -27.36 & -28.86 & -31.02 & -32.33 \\
\hline Maximum & -28.65 & -29.62 & -34.40 & -32.26 & -29.06 & -29.94 & -32.84 & -32.84 \\
\hline
\end{tabular}

${ }^{*}$ na $=$ not analysed

Paq proxy and $\delta^{13} \mathrm{C}$ signature for $n$-alkanes in the Piraquê-Açu River were quite stable, while PiraquêMirim River presented greater variation, implying more susceptibility to marine waters intrusion during dry period and the resulted flourishment of submerged macrophyte. Concerns about increasing rate of global climate change and extremely events on submerged macrophytes meadows is generally linked to distribution 
shifts and losses as a result of increased temperature stress, water depth and turbidity, and changes in the patterns of sexual reproduction (SHORT et al., 1999) but rarely linked to its invasion into estuarine environments due to the increase in marine waters intrusion as a result of prolonged dryness. In southern Brazil, the relationship between climatic/hydrological parameters and the distribution and abundance of estuarine submerged macrophyte presented high seasonal and interannual variability (COPERTINO, 2010; COPERTINO et al., 2010) with drastic reductions of seagrasses meadows after extreme precipitation and fluvial discharges (MÖLLER et al., 2009). Different from southern Brazil, southeast region has been suffered from prolonged dryness in the last decade, which may result in an invasion of submerged macrophyte into the PAMES, mainly in the Piraquê-Mirim River. Submerged macrophytes present different behavior and ecosystem services in relation to mangrove vegetation, as less efficiency in sediment trapping and protection against flood and erosion. When submerged macrophytes settles in the tidal flat they may inhibit establishment of mangrove seedlings or growth of saplings (CUNHA-LIGNON et al., 2011), resulting in losses of mangrove forest coverage.

\section{CONCLUSIONS}

Paq proxy applied on mid and long-chain $n$-alkanes homologues was a useful and enlightening tool, revealing input of submerged macrophyte as a result of marine water intrusion in a complex estuarine system surrounded by a dense mangrove forest. Discussed proxies ( $/ \mathrm{N}$ ratio, $n$-alkanes abundance, Paq and CPI) complemented each other and allowed the distinction of three different environments for each site in the PAMES: a stable mangrove environment in the Piraquê-Açu River; a mixed source but with mangrove dominance in the confluence; and a mangrove environment periodically disturbed by marine intrusion during dry period in the Piraquê-Mirim River.

The present study concludes that mangrove ecosystem in the Piraquê-Açu River presents greater resilience against drought while mangrove forest in the Piraquê-Mirim River should be managed with care in respect to freshwater catchment and dam construction. Although Paq application was successfully applied, its boundaries must be set carefully due to the natural variability of $n$-alkanes abundance in mangrove leaves as a result of decaying and salinity stress as well in submerged macrophyte species.

ACKNOWLEDGMENT: This work was supported by the Science and Technology Bureau of Espírito Santo State (FAPES), Coordination for the Improvement of Higher Education Personnel (CAPES), Ministry of Science, Technology, Innovations and Communications (Cnpq), the University of Liverpool (UK), the Department of Ecology and Oceanography (DOC) and the Post-Graduation Program in Environmental Oceanography (PPGOAM) of Federal University of Espírito Santo (UFES).

\section{REFERENCES}

ANKITA, Y.; MISHRA, P. K.; KUMAR, P.; JHA, D. K.; KUMAR, V. V.; AMBILI, V.; ANOOP, A.. Molecular distribution and carbon isotope of $n$-alkanes from Ashtamudi Estuary, South India:
Assessment of organic matter sources and paleoclimatic implications. Marine Chemistry, v.196, p.62-70, 2017. 
BARROSO, G. F.; MARTINS, F. C. O.; LÉLLIS, F. S.; SANTANA, S. E.. Integrated river basin management: incorporating coastal zone issues. In: BILIBIO, C.; HENSEL, O.; SELBACH, J. Sustainable water management in the tropics and subtropics and case studies in Brazil, Fundação. Bagé: Universidade Federal do Pampa, 2012. p.831-872.

BELLIGOTTI, F. M.; CARREIRA, R. S.; SOARES, M. L. G. Contribuição ao estudo do aporte de matéria orgânica em sistemas costeiros: hidrocarbonetos biogênicos em folhas de mangue. Geochimica Brasiliensis, v.21, n1, p.71-85, 2007.

BENEDICT, C. R.; WONG, W. W. L.; WONG, J. H. H... Fractionation of the stable isotopes of inorganic carbon by seagrasses. Plant Physiology, v.65, n.3, p.512-517, 1980.

BERTNESS, M. D.; WIKLER, K.; CHATKUPT, T.. Flood tolerance and the distribution of Iva frutescens across New England salt marshes. Oecologia, v.91, n.2, p.171-178, 1992. DOI: https://doi.org/10.1007/BF00317780

BLUMER, M.; GUILLARD, R. R. L.; CHASE, T.. Hydrocarbons of marine phytoplankton. Marine Biology, v.8, n.3, p.183-189, 1971. DOI: https://doi.org/10.1007/BF00355214

BOUILLON, S.; CONNOLLY, R. M.; LEE, S. Y.. Organic matter exchange e cycling in mangrove ecosystems: Recent insights from stable isotope studies. Journal of Sea Research, v.59, n.1-2, p.44-58, 2008. DOI: https://doi.org/10.1016/i.seares.2007.05.001

BRAY, E. E.; EVANS, E. D.. Distribution of $n$-paraffins as a clue to recognition of source beds. Geochimica et Cosmochimica Acta, v.22, n.1, p.2-15, 1961. DOI:

https://doi.org/10.1016/0016-7037(61)90069-2

CANUEL, E. A.; FREEMAN, K. H.; WAKEHAM, S. G.. Isotopic compositions of lipid biomarker compounds in estuarine plants e surface sediments. Limnology and Oceanography, v.42, n.7, p.1570-1583, 1997. DOI:

https://doi.org/10.4319/lo.1997.42.7.1570

CARDONA, P.; BOTERO, L.. Soil Characteristics and Vegetation Structure in a Heavily Deteriorated Mangrove Forest in the Caribbean Coast of Colombia. Biotropica, v.30, n.1, p.24-34, 1998. DOI: https://doi.org/10.1111/j.17447429.1998.tb00366.x

CHIKARAISHI, Y.; NARAOKA, H.. Compound-specific delta Ddelta C-13 analyses of $n$-alkanes extracted from terrestrial e aquatic plants. Phytochemistry, v.63, n.3, p.361-371, 2003. DOI: https://doi.org/10.1016/S0031-9422(02)00749-5

COLLISTER, J. W.; RIELEY, G.; STERN, B.; EGLINTON, G.; FRY, B.. Compound-specific $\delta^{13} \mathrm{C}$ analyses of leaf lipids from plants with differing carbon dioxide metabolisms. Organic Geochemistry, v.21, n.6-7, p.619-627, 1994. DOI: https://doi.org/10.1016/0146-6380(94)90008-6

COPERTINO, M. S.. Patos Lagoon - Climate variability and the state of seagrasses. Seagrass-Watch, v.40, p.4-5, 2010.

COPERTINO, M.; SEELIGER, U.. Hábitats de Ruppia maritima e de macroalgas. In: SEELIGER, U.; ODEBRECHT, C.. 0 Estuário da Lagoa dos Patos: um século de transformações. Rio Grande: FURG, 2010. p.92-98.
COPERTINO, M. S.; CREED, J. C.; LANARI, M. O.; MAGALHÃES, K.; BARROS, K.; LANA, P. C.; SORDO, L.; HORTA, P. A.. Seagrass and Submerged Aquatic Vegetation (VAS) Habitats off the Coast of Brazil: state of knowledge, conservation and main threats. Brazilian Journal of Oceanography, v.64, n.sp2, p.53-80, 2016. DOI: http://dx.doi.org/10.1590/S1679$875920161036064 \mathrm{sp} 2$

CRANWELL, P. A.. Chain-length distribution of $n$-alkanes from lake sediments in relation to postglacial environments. Freshwater Biology, v.3, n.3, p.259-265, 1973. DOI: https://doi.org/10.1111/j.1365-2427.1973.tb00921.x

CRANWELL, P. A.. Lipids of aquatic sediments and sedimenting particulates. Progress in Lipid Research, v.21, n.4, p.271-308, 1982. DOI: https://doi.org/10.1016/01637827(82)90012-1

CRANWELL, P. A.. Lipid geochemistry of sediments from Upton Broad, a small productive lake. Organic Geochemistry, v.7, n.1, p.25-37, 1984. DOI: https://doi.org/10.1016/0146-6380(84)90134-7

CUNHA-LIGNON, M.; KAMPEL, M.; MENGHINI, R.P.; SCHAEFFER-NOVELLI, Y.; CINTRÓN, G.; DAHDOUH-GUEBAS, F.. Mangrove Forests Submitted to Depositional Processes and Salinity Variation Investigated using satellite images and vegetation structure surveys. Journal of Coastal Research, v.64, Special Issue, p.344-348, 2011.

DEINES, P.. The isotopic composition of reduced organic carbon. In: FRITZ, P.; SOURCES, J. C. H.. Handbook of Environmental Isotope Geochemistry: The Terrestrial Environment. Amsterdam: Elsevier, 1980. p.329-406.

DEN HARTOG, C.; KUO, J.. Taxonomy and biogeography of seagrasses. In: ANTHONY, W. D.; ORTH, R. J.; DUARTE, C.. Seagrasses: biology, ecology and conservation. Dordrecht: Springer, 2007. p.1-23.

DUKE, N. C.; BALL, M. C.; ELLISON, J. C.. Factors influencing the biodiversity and distributional gradients in mangroves. Global Ecology and Biogeography Letters, v.7, n.1, p.27-47, 1998. DOI: https://doi.org/10.2307/2997695

EGLINTON, G.; HAMILTON, R.J .. Leaf epicuticular waxes. Science, v.156, n.3780, p.1322-1335, 1967. DOI: https://doi.org/10.1126/science.156.3780.1322

ELLISON, J. C.. Mangrove retreat with rising sea-level, Bermuda. Estuarine, Coastal and Shelf Science, v.37, n.1, p.75-87, 1993. DOI: https://doi.org/10.1006/ecss.1993.1042

ELLISON, J. C.; STODDART, D. R.. Mangrove Ecosystem Collapse during Predicted Sea-Level Rise: Holocene Analogues and Implications Journal of Coastal Research, v.7, n.1, p.151-165, 1991.

ELSTER, C.. Reasons for reforestation success and failure with tree mangrove species in Colombia. Forest Ecology and Management, v.131, n.1-3, p.201-214, 2000. DOI: https://doi.org/10.1016/S0378-1127(99)00214-5

FEITOZA, L. R.; CASTRO, L. L. F.; RESENDE, M.; ZANGRANDE, M. B.; STOCKING, M.; BOREL, R. M. A.; FULLIN, E. A.; CERQUEIRA, A. F.; SALGADO, J. S.; FEITOZA, H. N.; STOCK, L. A.; FILHO, M. D.. Map of natural units of Espirito Santo State, 
Brazil. International Institute for Aerial Survey and Earth Sciences, v.3-4, p.1- 38, 1997.

FIELD, C. D.. Impact of expected climate change on mangroves. Hydrobiologia, v.295, n.1-3, p.75-81, 1995. DOI: https://doi.org/10.1007/BF00029113

FICKEN, K. J.; LI, B.; SWAIN, D. L.; EGLINTON, G.. An n-alkane proxy for the sedimentary input of submerged/floating freshwater aquatic macrophytes. Organic Geochemistry, v.31, n.7-8, p.745-749, 2000. DOI:

https://doi.org/10.1016/S0146-6380(00)00081-4

FRANCE, R. L.; HOLMQUIST, J. G.. $\delta^{13} \mathrm{C}$ variability of macroalgae: effects of water motion via baffling by seagrasses and mangroves. Marine Ecology Progress Series, v.149, n.1-3, p.305-308, 1997. DOI: https://doi.org/10.3354/meps149305

GILMAN, E. L.; ELLISON, J.; DUKE, N. C.; FIELD, C.. Threats to mangroves from climate change and adaptation options: A review. Aquatic Botany, v.89, n.2, p.237-250, 2008. DOI: https://doi.org/10.1016/j.aquabot.2007.12.009

GRIMALT, J. O.; FERNÁNDEZ, P.; BAYONA, J. M.; ALBAIGÉS, J.. Assessment of fecal sterols and ketones as indicators of urban sewage inputs to coastal waters. Environmental Science and Technology, v.24, n.3, p.357-63, 1990. DOI: https://doi.org/10.1021/es00073a011

HEMMINGA, M. A.; MATEO, M. A.. Stable carbon isotopes in seagrasses: variability in ratios and use in ecological studies. Marine Ecology Progress Series, v.140, n.1, p.285-298, 1996. DOI: https://doi.org/10.3354/meps140285

HERNANDEZ, M. E.; MEAD, R.; PERALBA, M. C.; JAFFÉ, R.. Origin and transport of $n$-alkane-2-ones in a subtropical estuary: potential biomarkers for seagrass-derived organic matter. Organic Geochemistry, v.32, n.1, p.21-32, 2001. DOI: https://doi.org/10.1016/S0146-6380(00)00157-1

JAFFÉ, R.; MEAD, R.; HERNANDEZ, M. E.; PERALBA, M. C.; DIGUIDA, O. A.. Origin and transport of sedimentary organic matter in two subtropical estuaries: a comparative, biomarker-based study. Organic Geochemistry, v.32, n.4, p.507-526, 2001. DOI: https://doi.org/10.1016/S01466380(00)00192-3

JOHNSON, R. W.; CALDER, J. A.. Early diagenesis of fatty acids and hydrocarbons in a salt marsh environment. Geochimica et Cosmochimica Acta, v.37, n.8, p.1943-1955, 1973. DOI: https://doi.org/10.1016/0016-7037(73)90150-6

JIMÉNEZ, J. A.; LUGO, A. E.; CINTRÓN, G.. Tree Mortality in Mangrove Forests. Biotropica, v.17, n.3, p.177-185, 1985. DOI: https://doi.org/10.2307/2388214

JIMÉNEZ, J. A.. The structure and function of dry weather mangroves on the Pacific coast of Central America, with emphasis on Avicennia bicolor forests. Estuaries, v.13, n.2, p.182-192, 1990. DOI: https://doi.org/10.2307/1351588

KEMP, W. M.; BATIUK, R.; BARTLESON, R.; BERGSTROM, P.; CARTER, V.; GALLEGOS, C.; HUNLEY, W.; KARRH, L.; KOCH, E. W.; LANDWEHR, J. M.; MOORE, K. A.; MURRAY, L.; NAYLOR, M.; RYBICKI, N. B.; WILCOX, D. V.. Habitat requirements for submerged aquatic vegetation in Chesapeake Bay: Water quality, light regime, and physical- chemical factors.

Estuaries, v.27, n.3, p.363-377, 2004. DOI:

https://doi.org/10.1007/BF02803529

IEMA. Diagnóstico ambiental da Reserva Ecológica dos Manguezais Piraquê-açu e Piraquê-mirim. Aracruz: Jruano Consultoria e Serviços Ltda., 2010.

LEE, S. Y.; PRIMAVERA, J. H.; DAHDOUH-GUEBAS, F.; MCKEE, K.; BOSIRE, J. O.; CANNICCI, S.; DIELE, K.; FROMARD, F.; KOEDAM, N.; MARCHAND, C.; MENDELSSOHN, I.; MUKHERJEE, N.; RECORD, S.. Ecological role and services of tropical mangrove ecosystems: a reassessment. Global Ecology and Biogeography, v.23, n.7, p.726-743, 2014. DOI: https://doi.org/10.1111/geb.12155

LEITE, T. A.. Variação espacial e temporal da salinidade no sistema estuarino do rio Piraquê-açu (Aracruz, ES). Monografia (Graduação em Oceanografia) - Federal University of Espírito Santo, Vitória, 2012.

LIANG, S.; ZHOU, R. C.; DONG, S. S.; SHI, S. H.. Adaptation to salinity in mangroves: Implication on the evolution of salttolerance. Chinese Science Bulletin, v.53, n.11, p. 17081715, 2008. DOI: https://doi.org/10.1007/s11434-008-02219

MARGUILLIER, S.; VAN DER VELDE, G.; DEHAIRS, F.; HEMMINGA, M. A.; RAJAGOPAL, S.. Trophic relationships in an interlinked mangrove-seagrass ecosystem as traced by $\delta^{13} \mathrm{C}$ and $\delta^{15} \mathrm{~N}$. Marine Ecology Progress Series, v.151, n.1-3, p.115-121, 1997.

MARTIN, L.; SUGUIO, K.; FLEXOR, J. M.; ARCHANJO, J. D.. Coastal quaternary formations of the southern part of the state of Espírito Santo (Brazil). Anais da Academia Brasileira de Ciências, v.68, p.389-404, 1996.

MARQUES, L. V.; CREED, J. C.. Biologia e ecologia das fanerógamas marinhas do Brasil. Oecologia brasiliensis, v.12, n.2, p.315-331, 2008.

MEAD, R.; XU, Y.; CHONG, J.; JAFFÉ, R.. Sediment e soil organic matter source assessment as revealed by the molecular distribution e carbon isotopic composition of $n$ alkanes. Organic Geochemistry, v.36, n.3, p.363-370, 2005. DOI: https://doi.org/10.1016/j.orggeochem.2004.10.003

MEYERS, P. A.; ISHIWATARI, R.. Lacustrine organic geochemistry - an overview of indicators of organic matter sources and diagenesis in lake sediments. Organic Geochemistry, v.28, n.7, p.867-900, 1993. DOI: https://doi.org/10.1016/0146-6380(93)90100-P

MEYERS, P. A.. Organic geochemical proxies of paleoceanographic, paleolimnologic, e paleoclimatic processes. Organic Geochemistry, v.27, n.5-6, p.213-250, 1997. DOI: https://doi.org/10.1016/S0146-6380(97)00049-1

MONTEIRO, S. M.; SÁ, F.; NETO, R. R.. Geochemistry of suspended particulate matter in a tropical estuarine system, southeastern Brazil. Química Nova, v.40, n.8, p. 871-879, 2017. DOI: http://dx.doi.org/10.21577/0100-4042.20170085

O'LEARY, M. H.. Carbon isotope fractionation by plants. Phytochemistry, v.20, n.4, p.553-567, 1981. DOI: https://doi.org/10.1016/0031-9422(81)85134-5 
OGURA, K.; MACHIHARA, T.; TAKADA, H.. Diagenesis of biomarkers in Biwa lake sediments over 1 million years. Organic Geochemistry, v.16, n.4-6, p.805-813, 1990. DOI: https://doi.org/10.1016/0146-6380(90)90119-K

RAKOTOMAVO, A.; FROMARD, F.. Dynamics of mangrove forests in the Mangoky River delta, Madagascar, under the influence of natural and human factors. Forest Ecology and Management, v.259, n.6, p.1161-1169, 2010. DOI: https://doi.org/10.1016/j.foreco.2010.01.002

REDDY, C. M.; EGLINTON, T. I.; PALIC, R.; BENITEZ-NELSON, B. C.; STOJANOVIC, G.; PALIC, I.; DJORDJEVIC, S.; EGLINTON, G.. Even carbon number predominance of plant wax $n$ alkanes: a correction. Organic Geochemistry, v.31, n.4, p.331-336, 2000. DOI: https://doi.org/10.1016/S01466380(00)00025-5

RÖNNBÄCK, P.. The ecological basis for economic value of seafood production supported by mangrove ecosystems. Ecological Economics, v.29, n.2, p.235-252, 1999. DOI: https://doi.org/10.1016/S0921-8009(99)00016-6

SILVA, A. E.; QUARESMA, V. S.; BASTOS, A. C.. Sedimentological sectorization of an estuarine system in a regressive coast, southeast Brazil. Journal of Sedimentary Research, v.83, n.11, p.994-1003, 2013. DOI: https://doi.org/10.2110/isr.2013.78

SILVA, A. E.; MENANDRO, O. S.; NASCIMENTO, K. A.; QUARESMA, V. S.; BASTOS, A. C.. Interpretation of sedimentary processes using echo-character distribution: case study of Piraquê-Açu and Piraquê-Mirim estuarine system, Aracruz - ES (Brazil). Revista Brasileira de Geofísica, v.32, n.2, p.301-309, 2014. DOI:

https://doi.org/10.22564/rbgf.v32i2.484

SIKES, E. L.; UHLE, M. E.; NODDER, S. D.; HOWARD, M. E. Sources of organic matter in a coastal marine environment: Evidence from $n$-alkanes and their $\delta^{13} \mathrm{C}$ distributions in the Hauraki Gulf, New Zealand. Marine Chemistry, v.113, n.3-4, p.149-163, 2009. DOI:

https://doi.org/10.1016/j.marchem.2008.12.003

SIMONEIT, B. R. T.. Compound-specific carbon isotope analyses of individual long-chain alkanes e alkanoic acid in Harmattan aerosols. Atmospheric Environment, v.31, p.2225-2233, 1997. DOI: https://doi.org/10.1016/S13522310(97)00055-1

SNOUSSI, M.; KITHEKA, J.; SHAGHUDE, Y.; KANE, A.; ARTHURTON, R.; TISSIER, M. L.; VIRJI, H.. Downstream and
Coastal Impacts of Damming and Water Abstraction in Africa. Environmental Management, v.39, n.5, p.587-600, 2007. DOI: https://doi.org/10.1007/s00267-004-0369-2

SUN, Y.; CHEN, Z.; XU, S.; CAI, P.. Stable carbon e hydrogen isotopic fractionation of individual $n$-alkanes accompanying biodegradation: evidence from a group of progressively biodegraded oils. Organic Geochemistry, v.36, n.2, p.225238. DOI:

https://doi.org/10.1016/i.orggeochem.2004.09.002

THIBODEAU, P. T.; GARDNER, L. R.; REEVES, H. W.. The role of groundwater flow in controlling the spatial distribution of soil salinity and rooted macrophytes in a southeastern salt marsh, USA. Mangroves and Salt Marshes, v.2, n.1, p.1-13, 1998. DOI: https://doi.org/10.1023/A:1009910712539

VAN DONGEN, B. E.; SEMILETOV, I.; WEIJERS, J. W. H.; GUSTAFSSON, O. R.. Contrasting lipid biomarker composition of terrestrial organic matter exported from across the Eurasian Arctic by the five great Russian Arctic rivers. Global Biogeochemical Cycles, v.22, n.1, p.1-14, 2008. DOI: https://doi.org/10.1029/2007GB002974

VISO, A. C.; PESANDO, D.; BERNARD, P.; MARTY, J. C.. Lipid components of the Mediterranean seagrass Posidonia Oceanica. Phytochemistry, v.34, n.2, p.381-387, 1993. DOI: https://doi.org/10.1016/0031-9422(93)80012-H

VO, Q. T.; KUENZER, C.; VO, Q. M.; MODER, F.; OPPELT, N. . Review of valuation methods for mangrove ecosystem services. Ecological Indicators, v.23, p.431-446, 2012. DOI: https://doi.org/10.1016/j.ecolind.2012.04.022

XU, Y.; MEAD, R. N.; JAFFÉ, R.. A molecular marker-based assessment of sedimentary organic matter sources and distributions in Florida Bay. Hydrobiologia, v.569, n.1, p.179-192, 2006. DOI: https://doi.org/10.1007/s10750-006$\underline{0131-2}$

WANG, X. C.; CHEN, R. F.; BERRY, A.. Sources and preservation of organic matter in Plum Island salt marsh sediments (MA, USA): long-chain $n$-alkanes and stable carbon isotope compositions. Estuarine Coastal and Shelf Science, v.58, n.4, p.917-928, 2003. DOI: https://doi.org/10.1016/j.ecss.2003.07.006

WOODROFFE, C. D.. Geomorphology and development of Mangrove Swamps, Grand Cayman Island. Western Indian Ocean Journal of Marine Science, v.32, n.2, p.381-398, 1982. DOI: https://doi.org/10.1016/0025-3227(81)90085-2

A CBPC - Companhia Brasileira de Produção Científica (CNPJ: 11.221.422/0001-03) detém os direitos materiais desta publicação. Os direitos referem-se à publicação do trabalho em qualquer parte do mundo, incluindo os direitos às renovações, expansões e disseminações da contribuição, bem como outros direitos subsidiários. Todos os trabalhos publicados eletronicamente poderão posteriormente ser publicados em coletâneas impressas sob coordenação da Sustenere Publishing, da Companhia Brasileira de Produção Científica e seus parceiros autorizados. Os (as) autores (as) preservam os direitos autorais, mas não têm permissão para a publicação da contribuição em outro meio, impresso ou digital, em português ou em tradução. 